\title{
Tolerance of tropical fruits and a flower to carbonyl sulfide fumigation
}

\author{
Ching-Cheng Chen, Robert E. Paull * \\ Department of Horticulture, College of Tropical Agriculture and Human Resources, University of Hawaii at Manoa, \\ 3190 Maile Way, Honolulu, HI 96822, USA
}

Received 3 December 1997; accepted 3 July 1998

\begin{abstract}
The tolerance of 'Apple' banana (Musa sp.), avocado (Persea americana Mill.), mango (Mangifera indica L.), papaya (Carica papaya L.), and red ginger (Alpinia purpurata (Vieill.) K. Schum) inflorescences to carbonyl sulfide (COS) fumigation was studied. Commodities were exposed at $25^{\circ} \mathrm{C}$ to $\mathrm{COS}$ at various concentrations $(1-6 \%$ (v/v) for banana; $1 \%$ and $2 \%$ for the other fruits for various times from 1 to $24 \mathrm{~h}$. Fumigation of bananas with $4 \%$ for $1.5 \mathrm{~h}$, $2 \%$ for $2.5 \mathrm{~h}$ and $1 \%$ for $4 \mathrm{~h}$ did not cause significant skin or flesh injury when evaluated $7 \mathrm{~d}$ after treatment. Fumigated bananas and mango softened faster than unfumigated fruit when the treatment did not cause severe skin injury When the dosage and exposure time were increased for these fruit and the treatment caused severe or extreme skin injury, softening was delayed. COS treatments retarded papaya fruit skin coloration and flesh softening, while it promoted avocado softening. Avocado tolerated $1 \%$ for $7 \mathrm{~h}$ and $2 \%$ for less than $4 \mathrm{~h}$, while mango tolerated $1 \%$ for $3 \mathrm{~h}$ and $2 \%$ for $1 \mathrm{~h}$ and papaya $1 \%$ for $16 \mathrm{~h}$. Red ginger inflorescences were less tolerant of COS than fruit, being able to withstand $2 \%$ for less than $0.75 \mathrm{~h}$ and $1 \%$ for less than $2 \mathrm{~h}$. COS may be suitable as a fumigant for surface insects on papaya and avocado. (C) 1998 Elsevier Science B.V. All rights reserved.
\end{abstract}

Keywords: Disinfestation; Insect quarantine; Fruit ripening; Fumigation

* Corresponding author. Please address all correspondence to Robert E. Paull, CTAHR, Department of Horticulture Physiology, University of Hawaii, 3190 Maile Way, Honolulu, HI 96822, USA. Fax: +1808 9563542; e-mail: paull@hawaii.edu

\section{Introduction}

Fumigation is one of the most practical and convenient methods for insect disinfestation of fresh horticultural products (Paull and Armstrong, 1994). Nevertheless, insecticidal fumigants are toxic to mammals and many are flammable. Ethylene dibromide (EDB) was the most com- 
Table 1

Skin injury and flesh firmness of 'Apple' banana $7 \mathrm{~d}$ after exposure to COS fumigation treatment

\begin{tabular}{|c|c|c|c|c|}
\hline Experiment & $\operatorname{COS} \%(\mathrm{v} / \mathrm{v})$ & Exposure time (h) & Skin injury $(\%)^{\mathrm{a}}$ & Flesh firmness $(\mathrm{N})^{\mathrm{b}}$ \\
\hline \multirow[t]{4}{*}{1} & 0 & 2.5 & 1 & $10.4 \pm 1.1$ \\
\hline & 4 & 2.5 & 24 & $8.1 \pm 0.8$ \\
\hline & & 2.0 & 7 & $7.9 \pm 0.7$ \\
\hline & & 1.5 & 2 & $8.0 \pm 1.0$ \\
\hline \multirow[t]{4}{*}{2} & 0 & 7.0 & 2 & $12.4 \pm 1.7$ \\
\hline & 2 & 7.0 & 35 & $8.4 \pm 0.8$ \\
\hline & & 5.0 & 24 & $8.6 \pm 0.6$ \\
\hline & & 3.0 & 5 & $8.4 \pm 0.8$ \\
\hline \multirow[t]{4}{*}{3} & 0 & 5.0 & 1 & $14.4 \pm 8.5$ \\
\hline & 1 & 5.0 & 10 & $9.0 \pm 0.6$ \\
\hline & & 4.0 & 2 & $9.0 \pm 0.5$ \\
\hline & & 3.0 & 1 & $9.1 \pm 1.3$ \\
\hline \multirow[t]{4}{*}{4} & 0 & 4.0 & 1 & $16.6 \pm 10.6$ \\
\hline & 1 & 4.0 & 1 & $11.4 \pm 5.7$ \\
\hline & 2 & 2.5 & 1 & $9.8 \pm 1.5$ \\
\hline & 4 & 1.5 & 1 & $8.8 \pm 1.1$ \\
\hline
\end{tabular}

a The weighted means percentages reported were calculated from the transformed rating scale.

${ }^{\mathrm{b}}$ Mean \pm standard deviation.

monly used fumigant before being banned in 1984 by the USA Environment Protection Agency because of cancer risks (Anonymous, 1984). The alternatives, hydrogen cyanide (HCN) and phosphine (PH3) have only limited use because of phytotoxicity. Methyl bromide (MB) will be probably withdrawn in the near future as an ozone depletor (Anonymous, 1992).

A new fumigant, that is less toxic to mammals and does not harm the environment is needed to replace present fumigants. Carbonyl sulfide (COS) is a potential alternative for insect disinfestation, as it can effectively control some species of grain insects (Desmarchilier, 1994) and has been patented by the Australian Commonwealth Scientific and Industrial Research Organization (International Patent Application, PCT/AU93/00018). This fumigant is a trace gas in earth's atmosphere and is the major natural sulphur species in the atmosphere (Mihalopoulos et al., 1989). Its environmental fate has been reviewed (Kluczewski et al., 1985), and its decomposition in plants (Taylor et al., 1983) and phytotoxicity to bean plants studied (Taylor and Selvidge, 1984).

We report the possibility of using COS as a fumigant for insect disinfestation of fresh tropical horticultural commodities. 'Apple' bananas, av- ocado, mango, papaya, and red ginger inflorescences were exposed to various COS concentrations and exposure times. The effect of COS on ripening, skin injury, flesh firmness and appearance, and vase life of red ginger inflorescences was determined.

\section{Materials and methods}

Mature green 'Apple' bananas (cv. 'Santa Catarina Prata') were harvested from the Waimanalo Experiment Station, on the island of Oahu. Six clusters, (each with three fingers) were fumigated at $\approx 25^{\circ} \mathrm{C}$ in a $0.028 \mathrm{~m}^{3}$ chamber; load factor $\approx 7 \mathrm{~kg} \mathrm{~m}^{-3}$. The chamber was modified fiberglass vacuum desiccator (Labconco, Kansas City, Missouri) in which an electrically driven fan was used to ensure adequate circulation of gas within the enclosure and the vacuum ports modified to allow injection of COS using a syringe. Samples were exposed to $1 \%, 2 \%, 4 \%$ and $6 \%(\mathrm{v} / \mathrm{v}) \operatorname{COS}$ for $1-24 \mathrm{~h}$. The required volume of $\operatorname{COS}(96+\%)$ from a lecture bottle (Aldrich Chemical CO., Milwaukee, WI) was injected. After fumigation, fruit were aerated for $1 \mathrm{~h}$ before being allowed to ripen at $22^{\circ} \mathrm{C}$. Skin discoloration 


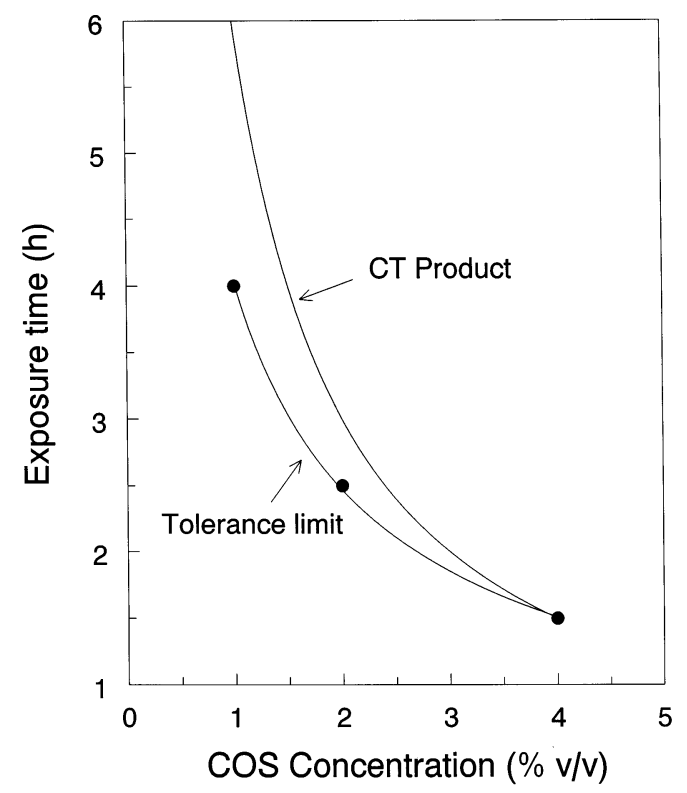

Fig. 1. The tolerance limit of 'Apple' banana exposed to COS fumigation at different concentrations $(\mathrm{v} / \mathrm{v})$ and exposure times at a $7 \mathrm{~kg} \mathrm{~m}^{-3}$ load factor. The $\mathrm{CT}$ product of the fumigant concentration by exposure time that gave a value of $6 \% \mathrm{~h}$ was plotted for comparison.

was subjectively evaluated $7 \mathrm{~d}$ after treatment, using percentage of affected skin area and a rating scale $(0$, no injury; $1,0-15 \% ; 2,16-50 \% ; 3$,
$51-85 \% ; 4,86-100 \%$ injury). Flesh firmness was measured $7 \mathrm{~d}$ after treatment with a penetrometer fitted with a $8 \mathrm{~mm}$ diameter tip.

Mature green avocado cv. 'Greengold', mango cv. 'Odorata', and papaya cv. 'Sunset' were harvested from the Poamoho Experiment Station on the island of Oahu. Eight fruit per treatment were fumigated in $0.028 \mathrm{~m}^{3}$ chambers at $25^{\circ} \mathrm{C}$ with load factors of $\approx 9 \mathrm{~kg} \mathrm{~m}^{-3}$ for avocado, $10 \mathrm{~kg} \mathrm{~m}^{-3}$ for mango, and $11 \mathrm{~kg} \mathrm{~m}^{-3}$ for papaya. Samples were exposed to $1 \%$ and $2 \%(\mathrm{v} / \mathrm{v}) \operatorname{COS}$ for $1-24$ $\mathrm{h}$, with separate treatments being in one of up to four chambers. After fumigation, fruit were aerated for $1 \mathrm{~h}$ before being allowed to ripen at $22^{\circ} \mathrm{C}$. Treatments were repeated in a series of four experiments to determine the injury threshold. Skin discoloration was subjectively evaluated $7 \mathrm{~d}$ after treatment for avocado and papaya, and $6 \mathrm{~d}$ after treatment for mango, using a percentage of affected area and a rating scale $(0$, no injury; 1 , $0-10 \% ; 2,11-35 \% ; 3,36-65 \% ; 4,66-90 \%$; , $91-100 \%$ injury). Flesh firmness was measured 7 d after treatment for avocado and papaya, and 6 $\mathrm{d}$ after treatment for mango, with a penetrometer fitted with a $8 \mathrm{~mm}$ diameter tip.

Red ginger inflorescences were harvested from the Poamoho Experiment Station. Ten flowers per

\section{Table 2}

Skin injury and flesh firmness of papaya $7 \mathrm{~d}$ after exposure to COS fumigation treatment. Skin injury was the percentage of area showing darkening injury using a pre-transformed rating scale from 0 to 5 (no injury to $100 \%$ injury)

\begin{tabular}{|c|c|c|c|c|}
\hline Experiment & $\cos \%(\mathrm{v} / \mathrm{v})$ & Exposure time (h) & Skin injury $(\%)^{\mathrm{a}}$ & Flesh firmness $(\mathrm{N})^{\mathrm{b}}$ \\
\hline \multirow[t]{4}{*}{1} & 0 & 16 & 0 & $2.8 \pm 1.4$ \\
\hline & 1 & 12 & 0 & $2.4 \pm 0.6$ \\
\hline & & 14 & 0 & $2.6 \pm 0.6$ \\
\hline & & 16 & 0 & $2.4 \pm 0.5$ \\
\hline \multirow[t]{4}{*}{2} & 0 & 20 & 0.5 & $2.3 \pm 0.5$ \\
\hline & 1 & 16 & 1 & $3.7 \pm 0.5$ \\
\hline & & 18 & 10 & $4.1 \pm 0.8$ \\
\hline & & 20 & 3 & $5.1 \pm 1.1$ \\
\hline \multirow[t]{4}{*}{3} & 0 & 12 & 0.5 & $1.8 \pm 0.2$ \\
\hline & 2 & 4 & 0.5 & $3.8 \pm 2.4$ \\
\hline & & 8 & 2 & $3.7 \pm 2.8$ \\
\hline & & 12 & 6 & $3.2 \pm 0.6$ \\
\hline \multirow[t]{4}{*}{4} & 0 & 10 & 1 & $1.9 \pm 0.4$ \\
\hline & 2 & 6 & 16 & $2.6 \pm 1.2$ \\
\hline & & 8 & 11 & $2.5 \pm 0.5$ \\
\hline & & 10 & 18 & $2.8 \pm 0.5$ \\
\hline
\end{tabular}

\footnotetext{
a The weighted means percentages reported were calculated from the transformed rating scale.

${ }^{\mathrm{b}}$ Mean \pm standard deviation.
} 
Table 3

Skin injury and flesh firmness of mango $6 \mathrm{~d}$ after exposure to COS fumigation treatment

\begin{tabular}{|c|c|c|c|c|}
\hline \multirow[t]{3}{*}{1} & 0 & 8 & 0 & $14.9 \pm 12.9$ \\
\hline & & 6 & 86 & $38.0 \pm 10.8$ \\
\hline & & 8 & 100 & $45.1 \pm 7.6$ \\
\hline \multirow[t]{2}{*}{2} & 0 & 4 & 0 & $9.0 \pm 3.4$ \\
\hline & & 4 & 77 & $53.0 \pm 7.6$ \\
\hline \multirow[t]{4}{*}{3} & 0 & 4 & 0 & $16.4 \pm 8.1$ \\
\hline & 1 & 2 & 0 & $11.6 \pm 3.5$ \\
\hline & & 3 & 2 & $14.5 \pm 5.3$ \\
\hline & & 4 & 29 & $26.5 \pm 12.8$ \\
\hline
\end{tabular}

${ }^{a}$ The weighted means percentages reported were calculated from the transformed rating scale.

${ }^{\mathrm{b}}$ Mean \pm standard deviation.

treatment were fumigated in a $120 \mathrm{~m}^{3}$ chamber with a load factor of $\approx 1 \mathrm{~kg} \mathrm{~m}^{-3}$. The chamber was constructed locally from lucite, with an electrically driven fan used to ensure adequate circulation of gas within the enclosure and a septum injection port. Samples were evaluated daily for injury and a loss of quality. Days from harvest to when $50 \%$ of area of an individual inflorescence was wilted or discolored was regarded as the end of vase life. Treatments were repeated in a series of experiments to determine the injury threshold.

\section{Results and discussion}

Exposing bananas to $6 \% \operatorname{COS}$ for $12 \mathrm{~h}$ caused severe brown-red discoloration of the skin and retarded flesh softening when evaluated $7 \mathrm{~d}$ after

Table 4

Skin injury and flesh firmness of avocado $7 \mathrm{~d}$ after exposure to COS fumigation treatment

\begin{tabular}{|c|c|c|c|c|}
\hline Experiment & $\cos \%(\mathrm{v} / \mathrm{v})$ & Exposure time (h) & Skin injury $(\%)^{\mathrm{a}}$ & Flesh firmness $(\mathrm{N})^{\mathrm{b}}$ \\
\hline \multirow[t]{4}{*}{1} & 0 & 7 & 0 & $47.0 \pm 30.9$ \\
\hline & 1 & 5 & 0 & $4.8 \pm 0.8$ \\
\hline & & 6 & 0 & $5.2 \pm 0.8$ \\
\hline & & 7 & 0 & $5.1 \pm 0.3$ \\
\hline \multirow[t]{4}{*}{2} & 0 & 12 & 0 & $33.8 \pm 32.1$ \\
\hline & 1 & 8 & 34.5 & $5.6 \pm 0.8$ \\
\hline & & 10 & 34.5 & $5.6 \pm 0.5$ \\
\hline & & 12 & 32 & $5.4 \pm 0.9$ \\
\hline \multirow[t]{4}{*}{3} & 0 & 8 & 1 & $10.2 \pm 8.0$ \\
\hline & 2 & 4 & 6 & $6.1 \pm 1.4$ \\
\hline & & 6 & 44 & $6.0 \pm 0.4$ \\
\hline & & 8 & 44 & $5.6 \pm 0.6$ \\
\hline
\end{tabular}

a The weighted means percentages reported were calculated from the transformed rating scale.

${ }^{\mathrm{b}}$ Mean \pm standard deviation. 
Table 5

Vase lives of red ginger inflorescences exposed to COS fumigation

\begin{tabular}{llll}
\hline Experiment & COS \% (v/v) & $\begin{array}{l}\text { Exposure } \\
\text { time }(\mathrm{h})\end{array}$ & $\begin{array}{l}\text { Vase lives } \\
(\mathrm{d})^{\mathrm{a}}\end{array}$ \\
\hline 1 & 0 & 2 & $16 \pm 5$ \\
& 1 & 2 & $13 \pm 5$ \\
2 & 0 & 1 & $20 \pm 4$ \\
3 & 2 & 1 & $12 \pm 2$ \\
& 0 & 0.75 & $18 \pm 5$ \\
& 2 & 0.75 & $14 \pm 5$ \\
\hline
\end{tabular}

${ }^{\text {a }}$ Mean \pm standard deviation.

treatment (data not shown). Longer exposure at $6 \%$ for $24 \mathrm{~h}$ caused extreme skin injury, completely inhibited flesh softening and caused offflavor. Shorter exposure at $2 \%$ for $2.5 \mathrm{~h}$ or $4 \%$ for $1.5 \mathrm{~h}$ did not cause significant skin or flesh injury, with $2 \%$ for $3 \mathrm{~h}$ or $4 \%$ for $2 \mathrm{~h}$ and $2 \%$ for $5 \mathrm{~h}$ and $7 \mathrm{~h}$ or $4 \%$ for $2.5 \mathrm{~h}$ causing only slight and moderate skin injury, respectively (Table 1). Exposure to $1 \%$ for $4 \mathrm{~h}$ did not cause significant skin injury while $1 \%$ for $5 \mathrm{~h}$ caused slight skin injury (Table 1). Some samples had slight peduncle injuries when fumigated at these lower rates. The tolerance limit for 'Apple' banana was found to be $4 \%$ for $1.5 \mathrm{~h}, 2 \%$ for $2.5 \mathrm{~h}$ and $1 \%$ for $4 \mathrm{~h}$ (Table 1). Fumigated banana softened faster than unfumigated fruit when the COS did not cause severe skin injury. Exposure time influenced the tolerance of 'Apple' banana to COS fumigation more than concentration (Fig. 1). This result was consistent with the responses of fruit to other fumigants such as methyl bromide (Claypool and Vines, 1956), and phosphine (Seo et al., 1979). 'Apple' banana tolerance to COS was low at the lower concentration, tolerating only $4 \mathrm{~h}$ at $1 \%$ (Fig. 1), whereas, the fumigant concentration by exposure time product of $6 \% \mathrm{~h}(4 \mathrm{~h} \times 1.5 \%)$ would suggest a tolerance of $6 \mathrm{~h}$ at $1 \%$.

Papaya tolerated $16 \mathrm{~h}$ exposure to $1 \%$ at a loading factor of $\approx 11 \mathrm{~kg} \mathrm{~m}^{-3}$. There was slight skin injury after $6 \mathrm{~h}$ at 2\% (Table 2), an olivegray skin darkening being observed. COS treatments retarded papaya fruit softening (Table 2) and skin coloration. Mango was more sensitive than papaya being only able to withstand $1 \%$
COS for less than $3 \mathrm{~h}$ and $1 \mathrm{~h}$ at $2 \%$ (Table 3 ), the skin showing a blotchy gray-green skin discoloration. The treatments that caused slight skin injury promoted fruit softening, while treatments that caused moderate or severe skin injury retarded fruit softening (Table 3) and caused offflavor. Avocado treated with $1 \% \operatorname{COS}$ for $7 \mathrm{~h}$ showed no skin injury while $2 \%$ for less than $4 \mathrm{~h}$ showed very slight skin injury (brown-red discoloration) (Table 4). Treating avocados with COS promoted fruit softening (Table 4). Avocado treated with COS were more susceptible to fruit rot that masked COS induced skin injury.

Red ginger flower tolerated less than $2 \mathrm{~h}$ at $1 \%$ COS and less than $0.75 \mathrm{~h}$ at $2 \%$ (Table 5). The red color of flower bracts turned purple in severe cases of COS phytotoxicity. There was seasonal variation in responses of ginger flowers to COS. In preliminary studies, Dendrobium orchid flower sprays were able to tolerate $2 \% \operatorname{COS}$ for $1.5 \mathrm{~h}$. Adult aphids on red ginger inflorescences were apparently controlled by $2 \% \operatorname{COS}$ for $1.5 \mathrm{~h}$ in initial observations.

The low load factor (less than 12\%) used in this study caused the COS concentration to remain nearer to its initial concentration and would be expected to cause more severe injury to commodities than the higher load factor anticipated in a commercial operation. This greater injury would be expected as more fumigant would be available per unit mass of fruit for absorption and hence higher absorbed residues on the fruit. It is also necessary to determine the COS residues after treatment before formal taste panel studies are performed or this fumigant is used commercially. At dose levels that caused noticeable skin injury, off-flavors were detected in the flesh in informal tasting, while none was apparent in treated fruit not showing skin injury.

The surface stages of some species of grain insects are controlled by a $24 \mathrm{~h}$ exposure to 0.0025 $\mathrm{kg} \mathrm{m} \mathrm{m}^{-3}(\approx 1 \%)$ (Desmarchilier, 1994). Insect stages that are inside a product are assumed to need longer exposure time or higher concentrations as different species of insects have different susceptibility to COS (Desmarchilier, 1994). The authors are not aware of any studies that report 
the toxic level of COS on fruit fly eggs or larvae in fruit. The tolerance limit of lethal dose (Fig. 1) for banana fruit suggests that the $1 \%(\mathrm{v} / \mathrm{v})$ for $4 \mathrm{~h}$ may not provide surface insect control for this fruit. Fresh commodities having either thick or dry skin (e.g. nuts), or only requiring the control of surface insects could be fumigated with COS. It may be therefore suitable for surface insects on papaya, avocado and some flowers.

\section{Acknowledgements}

This is the College of Tropical Agriculture and Human Resources Journal Series No. 4350. This research was funded by the USDA Special Grant for Minor Crop Research (59-5320-4-569). The authors wish to thank Nancy Chen and Gail Uruu for technical help.

\section{References}

Anonymous, 1984. Environmental Protection Agency. Rules and Regulations. Revocation of Tolerance Ethylene Dibromide. Federal Register 49, pp. 22082-22085.

Anonymous, 1992. Montreal protocol assessment supplement. Methyl bromide. United Nations Environment Pro- gramme. US Government Printing Office. Washington, D.C.

Claypool, L.L., Vines, H.M., 1956. Commodity tolerance studies of deciduous fruits to moist heat and fumigants. Hilgardia 24, 297-355.

Desmarchilier, J.M., 1994. Carbonyl sulphide as a fumigant for control of insects and mites. In: Highley, E., Wright, E.J., Banks, H.J., Champ, B.R. (Eds.), Proc. 6th International Working Confer. on Stored-Product Protection. CAB International, Wallingford, Oxon., UK. pp.78-82.

Kluczewski, S.M., Brown, K.A., Bell, J.N.B., 1985. Deposition of carbonyl sulphide in soils. Atmos. Environ. 19, 12951299.

Mihalopoulos, N., Bonsang, B., Nguyen, B.C., Kanakidou, M., Belviso, S., 1989. Field observations of carbonyl sulfide deficit near the ground: possible implication of vegetation. Atmos. Environ. 23, 2159-2188.

Paull, R.E., Armstrong, J.W., 1994. Insect pests and fresh horticultural products: treatments and responses. In: Paull, R.E., Armstrong, J.W. (Eds.), Insect Pests and Fresh Horticultural Products: Treatments and Responses. CAB International, Wallingford, Oxon. UK, pp. 1-36.

Seo, S.T., Akamine, E.K., Goo, T.T.S., Harris, E.J., Lee, C.Y.L., 1979. Oriental and Mediterranean fruit flies: fumigation of papaya, avocado, tomato, bell pepper, eggplant, and banana with phosphine. J. Econ. Entomol. 72, 354359.

Taylor, G.E., McLaughlin, S.B., Shiner, D.S., Selvidge, W.J., 1983. The flux of sulphur containing gases to vegetation. Atmos. Environ. 17, 789-796.

Taylor, G.E., Selvidge, W.J., 1984. Phytotoxicity in bush bean of fire sulphur-containing gases released from advanced fossil energy technologies. J. Environ. Qual. 13, 224-230. 